\title{
PENGARUH INOKULASI CENDAWAN MIKORIZA ARBUSKULAR DAN PUPUK NPK TERHADAP PERTUMBUHAN DAN HASIL TOMAT (Lycopersicum esculentum Mill.)
}

\section{THE EFFECT OF INOCULATION OF MYCORRHIZAL ARBUSCULAR FUNGI AND NPK FERTILIZER ON THE GROWTH AND YIELD OF TOMATOES (Lycopersicum esculentum Mill.)}

\author{
Suhardjadinata $^{1}$, Fitri Kurniati ${ }^{1}$ dan Dini Hanifah Nur Lulu ${ }^{1}$ \\ ${ }^{1}$ Program Studi Agroteknologi Fakultas Pertanian Universitas Siliwangi \\ Jl. Siliwangi No 24 Kota Tasikmalaya \\ Korespondensi : suharjadinata@unsil.ac.id
}

\begin{abstract}
ABSTRAK
Inokulasi cendawan mikoriza arbuskular (CMA) merupakan salah satu solusi untuk meningkatkan efisiensi penggunaan pupuk anorganik. Cendawan mikoriza berpotensi meningkatkan serapan unsur hara oleh akar tanaman, karena miselium cendawan mikoriza berperan sebagai perpanjangan akar dalam menyerap nutrisi dan air. Tujuan dari penelitian ini ialah untuk mengetahui interaksi antara inokulasi cendawan mikoriza arbuskular dengan pemupukan NPK terhadap pertumbuhan dan hasil tanaman tomat. Penelitian dilakukan dengan menggunakan Rancangan Acak Kelompok (RAK) pola faktorial dua faktor. Faktor pertama adalah dosis pupuk NPK yang terdiri dari 5 taraf yaitu, tanpa dipupuk NPK, dipupuk NPK 250 $\mathrm{kg} \mathrm{ha}^{-1}$, dipupuk NPK $500 \mathrm{~kg} \mathrm{ha}^{-1}$, dipupuk NPK $750 \mathrm{~kg} \mathrm{ha}^{-1}$, dan dipupuk NPK $1000 \mathrm{~kg} \mathrm{ha}^{-1}$. Faktor kedua yaitu inokulasi CMA yang terdiri dari 3 taraf yaitu tanpa inokulasi CMA,

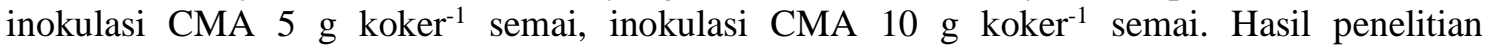
menunjukkan bahwa terdapat interaksi antara inokulasi CMA dengan pupuk NPK terhadap luas daun, jumlah buah per tanaman, bobot buah per butir, bobot buah per tanaman, dan bobot buah per petak dan konversi per hektar. Inokulasi CMA $10 \mathrm{~g}^{-10 k e r^{-1}}$ semai dan dipupuk dengan pupuk NPK $500 \mathrm{~kg} \mathrm{ha}^{-1}$ dan $750 \mathrm{~kg} \mathrm{ha}^{-1}$ dapat mengefisiensikan pengunakan pupuk NPK antara $25 \%$ sampai $50 \%$ dan meningkatkan hasil sebesar 7,09\% sampai 7,82\% dari penggunaan pupuk NPK anjuran/ rekomendasi.
\end{abstract}

Kata kunci: mikoriza, pupuk NPK, tomat. 


\begin{abstract}
Inoculation of arbuscular mycorrhizal fungi (AMF) is one solutions to improve the efficiency of the use of inorganic fertilizers. Mycorrhizal fungi have the potential to improve the absorption of nutrients by plant roots, because the mycelium of mycorrhizal fungi afford of acting as an extension of the roots to absorb the nutrients and water. The aim of this study was to determine the interaction between arbuscular mycorrhizal fungi inoculation and NPK fertilization on the growth and yield of tomatoes. The study was conducted using a two-factor factorial randomized block design. The first factor is the dose of NPK fertilizer which consists of 5 levels i.e., without NPK fertilized, fertilized with NPK $250 \mathrm{~kg} \mathrm{ha}^{-1}$, with NPK $500 \mathrm{~kg} \mathrm{ha-}{ }^{1}$, with NPK $750 \mathrm{~kg} \mathrm{ha}^{-1}$, and with NPK $1000 \mathrm{~kg} \mathrm{ha}^{-1}$. The second factor is the inoculation of AMF which consists of 3 levels i.e., without AMF inoculation, with $5 \mathrm{~g} \mathrm{seed}^{-1}$ container, with 10 $\mathrm{g} \mathrm{seed}^{-1}$ container. The results showed that there is interaction between AMF inoculation with NPK fertilizer on the leaf area, the number of fruit per plant, the fruit weight per plant, and the fruit weight per plot and conversions per hectare. Inoculation of AMF with $10 \mathrm{~g} \mathrm{seed}^{-1}$ containers and NPK fertilizer with $500 \mathrm{~kg} \mathrm{ha}^{-1}$ and $750 \mathrm{~kg} \mathrm{ha}^{-1}$ can efficiently improve of the use of NPK fertilizer between $25 \%$ to $50 \%$ and attain to improve the yields by $7,09 \%$ to $7,82 \%$ of NPK fertilizer recommended use.
\end{abstract}

Key words : mycorrhizal, NPK fertilization, tomatoes.

\section{PENDAHULUAN}

Tomat merupakan salah satu komoditas hortikultura yang bernilai ekonomi tinggi dan masih memerlukan penanganan serius, terutama dalam hal peningkatan kuantitas dan kualitas hasilnya (Kementerian Pertanian, 2018). Konsumsi tomat semakin meningkat setiap tahunnya seiring dengan bertambahnya jumlah penduduk. Berdasarkan data Survei Sosial Ekonomi Nasional (SUSENAS) konsumsi tomat sayur untuk kebutuhan rumah tangga pada tahun tahun 2018 sebesar 4,43 kg per kapita per tahun. Produksi tomat dalam negeri pada tahun 2018 sebesar 976.772 ton (Kementerian Pertanian, 2019).

Rata-rata produktivitas tomat di Indonesia masih rendah yaitu sebesar 18,14 t ha ${ }^{-1}$ (Kementerian Pertanian, 2019), ratarata produktivitas tersebut masih jauh di bawah potensi hasil tomat yang dapat mencapai $45 \mathrm{t} \mathrm{ha}^{-1}$ sampai $75 \mathrm{t} \mathrm{ha}$. Peningkatan produktivitas tomat tidak terlepas dari pemenuhan kebutuhan unsur hara bagi tanaman. Unsur hara utama yang dibutuhkan oleh tanaman adalah nitrogen, fosfor, dan kalium. Unsur-unsur hara tersebut diaplikasikan pada tanaman umumnya berasal dari pupuk anorganik (kimia). Menurut Subhan et al. (2009), petani umumnya memupuk tanaman tomat dengan pupuk majemuk NPK (15-15-15) dosis $1.000 \mathrm{~kg} \mathrm{ha}^{-1}$.

Salah satu faktor yang menyebabkan rendahnya produksi tomat adalah penggunaan pupuk yang kurang optimal (Wasonowati, 2011). Penggunaan pupuk yang kurang optimal ini disebabkan oleh pupuk yang diberikan ke tanaman tidak seluruhnya diserap oleh tanaman. Tanaman hanya menggunakan sekitar 50\% dari pupuk $\mathrm{N}$ yang diberikan, selebihnya hilang dari sistem perakaran tanaman melalui pencucian, penguapan, denitrifikasi dan faktor lainnya. Pemberian pupuk $\mathrm{P}$ hanya $15 \%$ sampai $20 \%$ yang dapat diserap oleh tanaman, sedangkan sisanya akan terjerap oleh koloid tanah dan tinggal sebagai residu tanah. Unsur $\mathrm{K}$ merupakan hara yang mobil di dalam tanah dan bersifat dinamis sehingga unsur K mudah tercuci (Herman et al., 2012). 
Suwahyono (2011) menyatakan bahwa penggunaan pupuk anorganik secara terus-menerus selain berdampak negatif terhadap produktivitas tanah dan produktivitas tanaman juga sering tidak efisien. Untuk meningkatkan efesiensi penggunaan pupuk NPK, diperlukan terobosan teknologi melalui sistem pengelolaan hara tanaman terpadu (integrated plant nutrient management system) dengan menerapkan pupuk berimbang. Pengelolaan hara tanaman terpadu salah satunya dapat dilakukan dengan cara mengkombinasikan penggunaan pupuk anorganik dengan pupuk hayati.

Pemanfaatan mikoriza sebagai pupuk hayati merupakan salah satu alternatif untuk meningkatkan efisiensi penggunaan pupuk anorganik. Cendawan mikoriza abskular adalah mikroba tanah yang mampu bersimbiosis dengan banyak tanaman dan tersebar di berbagai agroekosistem (Sastrahidayat, 2010). Cendawan mikoriza abskular memiliki potensi dalam meningkatkan serapan unsur hara oleh akar tanaman, karena miselium cendawan mikoriza mampu berperan sebagai perpanjangan akar dalam menyerap nutrisi dan air yang tidak terjangkau oleh akar sehingga permukaan akar bertambah luas (Agustin et al., 2010).

Trisilawati et al. (2012) menyatakan bahwa inokulasi cendawan mikoriza arbuskular (CMA) dapat menurunkan dosis penggunaan pupuk NPK sampai 50\% dari dosis rekomendasi dengan tidak menurunkan produktivitas. Hal ini menunjukkan bahwa inokulasi mikoriza mampu mengefisiensikan penggunaan pupuk NPK.

Menurut Hadianur et al. (2017), aplikasi mikoriza pada tanaman mampu meningkatkan serapan hara $\mathrm{N}, \mathrm{P}$, dan $\mathrm{K}$. Hasil penelitian Pratiwi (2016), menunjukkan bahwa aplikasi pupuk NPK 15-15-15 dengan dosis 2,5 $\mathrm{g} \mathrm{tan}^{-1}$ yang dikombinasikan dengan pupuk hayati mikoriza $5 \mathrm{~g} \mathrm{tan}^{-1}$, dapat meningkatkan serapan unsur $\mathrm{N}, \mathrm{P}$, dan $\mathrm{K}$ pada tanaman melon, serta meningkatkan pertumbuhan dan hasil buah melon.

Berdasarkan hal tersebut, maka penelitian ini dilakukan dengan tujuan untuk mengetahui interaksi terbaik antara inokulasi cendawan mikoriza arbuskular (CMA) dengan pemupukan NPK terhadap pertumbuhan dan hasil tomat, serta efisiensi penggunaan pupuk NPK dalam sistem pengelolaan hara tanaman terpadu pada budidaya tanaman tomat.

\section{BAHAN DAN METODE}

Penelitian dilakukan di lahan petani Desa Pakemitan Kidul, Kecamatan Ciawi, Kabupaten Tasikmalaya pada ketinggian tempat 532 mdpl dan jenis tanah latosol, pada bulan April sampai Agustus 2019. Penelitian menggunakan Rancangan Acak Kelompok (RAK) pola faktorial dua faktor dengan tiga ulangan. Faktor pertama adalah dosis pupuk NPK yang terdiri dari 5 taraf, yaitu tanpa dipupuk NPK, dipupuk NPK $250 \mathrm{~kg} \mathrm{ha}^{-1}$, dipupuk NPK $500 \mathrm{~kg} \mathrm{ha}^{-1}$, dipupuk NPK $750 \mathrm{~kg} \mathrm{ha}^{-1}$, dan dipupuk NPK $1000 \mathrm{~kg} \mathrm{ha}^{-1}$. Faktor kedua adalah dosis inokulan CMA yang terdiri dari 3 taraf, yaitu tanpa inokulan CMA, inokulan CMA 5 g koker-1 semai dan 10 g koker $^{-1}$ semai. Varietas tomat yang digunakan yaitu varietas Servo. CMA diaplikasikan bersamaan dengan menyemaikan benih pada koker semai dengan cara dimasukkan ke dalam koker semai (polybag $6 \mathrm{~cm}$ x $8 \mathrm{~cm}$ ) yang telah berisi media campuran tanah dan pupuk kandang (1:1). Teknologi budidaya tomat menggunakan sistem guludan dengan dua baris tanaman per guludan dengan jarak tanam $60 \mathrm{~cm} \times 50 \mathrm{~cm}$. Pemupukan NPK dilakukan dua kali, yaitu masing-masing sebanyak $50 \%$ dari dosis perlakuan pupuk NPK pada saat tanam dan pada 30 hari setelah tanam, dengan cara dimasukan pada lubang pupuk dengan jarak 5-7 $\mathrm{cm}$ dari lubang tanam. Parameter yang diamati 
adalah tinggi tanaman, luas daun, jumlah buah per tanaman, bobot buah per tanaman, bobot buah konversi ke hektar.

\section{HASIL DAN PEMBAHASAN}

\section{Tinggi tanaman}

Hasil analisis ragam menunjukkan tidak terdapat interaksi antara inokulasi cendawan mikoriza arbuskular (CMA) dengan pupuk NPK terhadap tinggi tanaman tomat, tetapi secara mandiri pemupukan NPK berpengaruh nyata terhadap tinggi tanaman tomat pada umur 65 HST. Pengaruh inokulasi CMA dan pemupukan NPK terhadap tinggi tanaman tomat pada 65 HST dapat dilihat pada Tabel 1.

Tabel 1. Pengaruh inokulasi CMA dan pemupukan NPK terhadap tinggi tanaman tomat $(\mathrm{cm})$ pada 65 HST

\begin{tabular}{ccccc}
\hline $\begin{array}{c}\text { Dosis } \\
\text { pupuk }\end{array}$ & \multicolumn{4}{c}{$\begin{array}{c}\text { Inokulasi CMA } \\
\text { (g koker }\end{array}$} \\
\cline { 2 - 5 } $\begin{array}{c}\text { NPK } \\
\left(\mathrm{kg} \mathrm{ha}^{-1}\right)\end{array}$ & 0 & 5 & 10 & Rerata \\
\hline \multicolumn{4}{c}{$-----\mathrm{cm}^{------}$} \\
0 & 102,96 & 105,83 & 104,96 & $104,5 \mathrm{a}$ \\
250 & 118,21 & 125,25 & 124,79 & $124,08 \mathrm{~b}$ \\
500 & 120,75 & 127,85 & 126,88 & $127,49 \mathrm{~b}$ \\
750 & 122,42 & 127,83 & 127,58 & $126,94 \mathrm{~b}$ \\
1000 & 122,13 & 126,95 & 126,75 & $126,28 \mathrm{~b}$ \\
\hline Rerata & 117,29 & 122,74 & 122,19 \\
\multicolumn{4}{c}{} \\
& $\mathrm{A}$ & $\mathrm{A}$ & $\mathrm{A}$ \\
\hline
\end{tabular}

Keterangan : Angka rerata yang diikuti huruf besar yang sama arah horizontal dan huruf kecil yang sama arah vertikal tidak berbeda menurut uji jarak berganda Duncan pada taraf nyata $5 \%$.

Pada Tabel 1 menunjukkan bahwa tanaman tomat yang dipupuk NPK menghasilkan tinggi tanaman lebih tinggi dan berbeda nyata dibandingkan dengan yang tidak dipupuk NPK. Tetapi pemupukan NPK dengan dosis $250 \mathrm{~kg} \mathrm{ha}^{-1}$ sampai dengan $1000 \mathrm{~kg} \mathrm{ha}^{-1}$ satu sama lainnya berbeda tidak nyata.
Pertumbuhan tinggi batang terjadi di dalam meristem apikal batang, batang memanjang sebagai akibat meningkatnya jumlah sel. Untuk pertumbuhan tanaman yang normal memerlukan unsur hara dalam jumlah dan konsentrasi yang optimum serta berada dalam keseimbangan di dalam tanah (Nainggolan, 2011). Unsur hara N, P, dan K berfungsi untuk mendukung proses fotosintesis dan produksi fotosintat yang dihasilkan, serta meningkatkan pertumbuhan tanaman melalui mekanisme pengubahan unsur hara menjadi senyawa organik atau energi. Unsur hara tersebut tidak dapat digantikan unsur hara lain untuk memenuhi siklus hidup tanaman.

Inokulasi CMA menunjukkan pengaruh tidak nyata terhadap tinggi tanaman tomat, namun demikian, inokulasi CMA pada setiap taraf dosis pupuk NPK cenderung menghasilkan tinggi tanaman lebih tinggi dibandingkan dengan perlakuan yang tanpa inokulasi CMA. Hal ini diduga karena mikoriza yang menginfeksi perakaran tanaman dapat memproduksi jaringan hifa eksternal yang tumbuh secara ekspansif, sehingga dapat meningkatkan kapasitas akar dalam penyerapan unsur hara. Afrinda dan Islami (2018) menyatakan bahwa aplikasi mikoriza efektif dalam mengoptimalkan pertumbuhan tanaman. Menurut Hadianur et al. (2017), aplikasi mikoriza pada tanaman mampu meningkatkan serapan hara N, P, dan K. Prayudyaningsih (2014) menyatakan hifa CMA yang menginfeksi akar tanaman mempunyai kemampuan yang tinggi dalam meningkatkan kapasitas penyerapan unsur fosfat, nitrogen, sulfur, seng dan unsur-unsur esensial lainnya.

\section{Luas daun}

Hasil analisis ragam menunjukkan terdapat interaksi yang nyata antara inokulasi CMA dengan pemupukan NPK terhadap luas daun tomat pada umur 65 hst (Tabel 2). 
Tabel 2. Pengaruh interaksi antara inokulasi CMA dengan pemupukan NPK terhadap luas daun per tanaman $\left(\mathrm{cm}^{2}\right)$ pada umur $65 \mathrm{hst}$

\begin{tabular}{cccc}
\hline $\begin{array}{c}\text { Dosis } \\
\text { pupuk } \\
\text { NPK } \\
\left(\mathrm{kg} \mathrm{ha}^{-1}\right)\end{array}$ & \multicolumn{3}{c}{$\begin{array}{c}\text { Inokulasi CMA } \\
(\mathrm{g} \text { koker }\end{array}{ }^{-1}$ semai $)$} \\
\cline { 2 - 4 } 0 & 0 & 5 & 10 \\
\hline & $3252 \mathrm{a}$ & $3390 \mathrm{a}$ & $3361 \mathrm{a}$ \\
& $\mathrm{A}$ & $\mathrm{A}$ & $\mathrm{A}$ \\
250 & $4605 \mathrm{~b}$ & $5376 \mathrm{~b}$ & $5463 \mathrm{~b}$ \\
& $\mathrm{~A}$ & $\mathrm{~B}$ & $\mathrm{~B}$ \\
500 & $5481 \mathrm{c}$ & $6794 \mathrm{c}$ & $6822 \mathrm{c}$ \\
& $\mathrm{A}$ & $\mathrm{B}$ & $\mathrm{B}$ \\
750 & $5864 \mathrm{c}$ & $6819 \mathrm{c}$ & $6824 \mathrm{c}$ \\
& $\mathrm{A}$ & $\mathrm{B}$ & $\mathrm{B}$ \\
1000 & $6821 \mathrm{~d}$ & $6953 \mathrm{c}$ & $7029 \mathrm{c}$ \\
& $\mathrm{A}$ & $\mathrm{A}$ & $\mathrm{A}$ \\
\hline
\end{tabular}

Keterangan : Angka rerata yang diikuti huruf besar yang sama arah horizontal dan huruf kecil yang sama arah vertikal tidak berbeda menurut uji jarak berganda Duncan pada taraf nyata $5 \%$.

Pada Tabel 2 terlihat bahwa respon tanaman tomat terhadap inokulasi CMA berbeda tergantung pada dosis pupuk NPK yang diberikan. Demikian pula sebaliknya, respon tanaman tomat terhadap pemupukan NPK berbeda tergantung pada dosis inokulan CMA.

Inokulasi CMA pada perlakuan tanpa dipupuk NPK dan yang dipupuk NPK dosis $1000 \mathrm{~kg} \mathrm{ha}^{-1}$ tidak berpengaruh nyata terhadap luas daun. Sedangkan pada perlakukan yang dipupuk NPK dosis 250 $\mathrm{kg} \mathrm{ha} \mathrm{h}^{-1}, 500 \mathrm{~kg} \mathrm{ha}^{-1}$, dan $750 \mathrm{~kg} \mathrm{ha}{ }^{-1}$, inokulasi CMA menghasilkan luas daun lebih luas dan berbeda nyata dibandingkan dengan perlakuan yang tidak diinokulasi CMA.

Inokulasi CMA dosis $5 \mathrm{~g} \mathrm{koker}^{-1}$ semai dengan $10 \mathrm{~g}$ koker $^{-1}$ semai berbeda tidak nyata pada semua taraf perlakuan dosis NPK tersebut di atas. Hal ini menunjukkan bahwa inokulasi CMA dengan dosis 5 g koker $^{-1}$ semai sudah cukup untuk menginfeksi akar tanaman dalam meningkatkan kapasitas penyerapan unsur fosfat, nitrogen, dan kalium, dan unsurunsur esensial lainnya yang dibutuhkan tanaman, sehingga pertumbuhan tanaman tomat meningkat.

Pemupukan NPK menunjukkan pengaruh yang nyata terhadap luas daun pada semua taraf perlakuan dosis inokulan CMA. Pada perlakuan tanpa inokulasi CMA menunjukkan bahwa semakin tinggi dosis pupuk NPK yang diberikan semakin luas daunnya. Luas daun tertinggi pada perlakuan tanpa inokulasi CMA didapat pada perlakuan pemupukan NPK $1000 \mathrm{~kg}$ ha $^{-1}$ yang berbeda nyata dengan perlakuan yang dipupuk NPK dosis $250 \mathrm{~kg} \mathrm{ha}^{-1}, 500$ $\mathrm{kg} \mathrm{ha}{ }^{-1}$ dan $750 \mathrm{~kg} \mathrm{ha}^{-1}$. Hal ini karena terpenuhi kebutuhan unsur hara N, P dan $\mathrm{K}$ pada dosis tersebut. Dosis pupuk NPK 1000 $\mathrm{kg} \mathrm{ha}{ }^{-1}$ merupakan dosis yang umum digunakan oleh petani tomat.

Pada perlakuan inokulasi CMA $5 \mathrm{~g}$ koker $^{-1}$ semai dan $10 \mathrm{~g} \mathrm{koker}^{-1}$ semai, antara pemupukan NPK dosis $500 \mathrm{~kg} \mathrm{ha}^{-1}, 750 \mathrm{~kg}$ $\mathrm{ha}^{-1}$ dan $1000 \mathrm{~kg} \mathrm{ha}^{-1}$ berbeda tidak nyata. Pada Tabel 2 juga terlihat bahwa pemupukan NPK dengan dosis $500 \mathrm{~kg} \mathrm{ha}^{-1}$ dan $750 \mathrm{~kg}$ $\mathrm{ha}^{-1}$ dengan inokulasi CMA $5 \mathrm{~g}$ koker $^{-1}$ semai dan $10 \mathrm{~g}$ koker $^{-1}$ semai menghasilkan luas daun lebih luas dibandingkan dengan perlakuan yang dipupuk NPK $1000 \mathrm{~kg} \mathrm{ha}^{-1}$ tanpa diinokulasi CMA. Hal ini diduga karena inokulasi CMA dapat meningkatkan serapan unsur hara tanah oleh akar tanaman, sehingga dapat meningkatkan efektifitas dan efisiensi penggunaan pupuk NPK.

CMA dapat meningkatkan serapan unsur hara tanaman terutama unsur $\mathrm{N}, \mathrm{P}$, dan $\mathrm{K}$, karena hifa eksternal cendawan mikoriza dapat meningkatkan zona penyerapan pada daerah rizosfer, sehingga pasokan hara menjadi lebih baik (Simarmata, 2005). Pasokan N, P, dan K yang optimum akan menghasilkan pertumbuhan tanaman yang baik (Handayanto et al., 2017). Trisilawati et al., (2012) menyatakan bahwa pertumbuhan tanaman yang baik pada 
tanaman bermikoriza disebabkan karena mikoriza dapat memperluas volume sebaran perakaran dalam tanah, sehingga hara lebih tersedia bagi tanaman. Adetya et al., (2018), menyatakan lebih dari $50 \%$ kebutuhan $\mathrm{N}$ tumbuhan dipasok oleh asosiasi mikoriza. Hifa cendawan mikoriza arbuskular mampu memanfaatkan $\mathrm{N}$ dan $\mathrm{P}$ anorganik secara efisien dan mentransfernya ke dalam tanah dalam jarak $10 \mathrm{~cm}$ sampai $30 \mathrm{~cm}$. Hal ini menunjukkan bahwa cendawan mikoriza arbuskular memungkinkan tanaman inang untuk memiliki akses dan melakukan penyerapan unsur hara secara maksimal yang tidak terjangkau oleh tanaman.

\section{Jumlah buah per tanaman}

Hasil analisis ragam menunjukkan terdapat interaksi yang nyata antara inokulasi CMA dengan pemupukan NPK terhadap jumlah buah tomat per tanaman seperti tertera pada Tabel 3.

Tabel 3. Pengaruh interaksi antara inokulasi CMA dengan pemupukan NPK terhadap jumlah buah tomat per tanaman

\begin{tabular}{cccc}
\hline $\begin{array}{c}\text { Dosis } \\
\text { pupuk } \\
\text { NPK } \\
\left(\mathrm{kg} \mathrm{ha}^{-1}\right)\end{array}$ & \multicolumn{4}{c}{$\begin{array}{c}\text { Inokulasi CMA } \\
\left.\text { (g koker }{ }^{-1} \text { semai }\right)\end{array}$} \\
\cline { 2 - 4 } 0 & 0 & 5 & 10 \\
\hline \multicolumn{4}{c}{-----buah----- } \\
& $18,10 \mathrm{a}$ & $18,19 \mathrm{a}$ & $19,71 \mathrm{a}$ \\
250 & $\mathrm{~A}$ & $\mathrm{~A}$ & $\mathrm{~A}$ \\
& $22,24 \mathrm{a}$ & $31,81 \mathrm{~b}$ & $37,96 \mathrm{~b}$ \\
500 & $\mathrm{~A}$ & $\mathrm{~B}$ & $\mathrm{~B}$ \\
& $43,05 \mathrm{~b}$ & $52,43 \mathrm{c}$ & $54,90 \mathrm{c}$ \\
750 & $\mathrm{~A}$ & $\mathrm{~B}$ & $\mathrm{~B}$ \\
& $44,90 \mathrm{~b}$ & $53,93 \mathrm{c}$ & $52,14 \mathrm{c}$ \\
1000 & $\mathrm{~A}$ & $\mathrm{~B}$ & $\mathrm{~B}$ \\
& $50,24 \mathrm{c}$ & $52,48 \mathrm{c}$ & $52,38 \mathrm{c}$ \\
& $\mathrm{A}$ & $\mathrm{A}$ & $\mathrm{A}$ \\
\hline
\end{tabular}

Keterangan : Angka rerata yang diikuti huruf besar yang sama arah horizontal dan huruf kecil yang sama arah vertikal tidak berbeda menurut uji jarak berganda Duncan pada taraf nyata 5\%.
Pada Tabel 3 dapat dilihat bahwa interaksi antara inokulasi CMA dengan pemupukan NPK berpengaruh nyata terhadap jumlah buah per tanaman. Respon tanaman tomat terhadap inokulasi CMA berbeda-beda tergantung pada dosis pupuk NPK. Demikian pula sebaliknya, respon tanaman tomat terhadap pemupukan NPK berbeda-beda tergantung pada dosis inokulan CMA.

Inokulasi CMA pada perlakuan tanpa dipupuk NPK dan yang dipupuk NPK dosis $1000 \mathrm{~kg} \mathrm{ha}^{-1}$ berpengaruh tidak nyata terhadap jumlah buah per tanaman. Inokulasi CMA pada perlakukan yang dipupuk NPK dosis $250 \mathrm{~kg} \mathrm{ha}^{-1}, 500 \mathrm{~kg}$ $\mathrm{ha}^{-1}$, dan $750 \mathrm{~kg} \mathrm{ha}^{-1}$ menghasilkan jumlah buah per tanaman lebih tinggi dan berbeda nyata dibandingkan dengan perlakuan yang tanpa inokulasi CMA. Inokulasi CMA dosis $5 \mathrm{~g} \mathrm{koker}^{-1}$ semai dengan dosis $10 \mathrm{~g} \mathrm{koker}^{-1}$ semai berbeda tidak nyata pada semua taraf perlakuan dosis NPK tersebut di atas.

Jumlah buah per tanaman terbanyak pada perlakuan yang tidak inokulasi CMA didapat pada perlakuan pemupukan NPK $1000 \mathrm{~kg} \mathrm{ha}^{-1}$ yang berbeda nyata dengan perlakuan yang dipupuk NPK dosis $250 \mathrm{~kg}$ $\mathrm{ha}^{-1}, 500 \mathrm{~kg} \mathrm{ha}^{-1}$ dan $750 \mathrm{~kg} \mathrm{ha}{ }^{-1}$. Pada perlakuan yang inokulasi CMA $5 \mathrm{~g} \mathrm{koker}^{-1}$ semai dan $10 \mathrm{~g} \mathrm{koker}^{-1}$ semai, pemupukan NPK dosis $500 \mathrm{~kg} \mathrm{ha}^{-1}, 750 \mathrm{~kg} \mathrm{ha}^{-1}$ dan $1000 \mathrm{~kg} \mathrm{ha}^{-1}$ menghasilkan jumlah buah per tanaman berbeda tidak nyata.

Pada penelitian ini diketahui bahwa pemupukan NPK dosis $500 \mathrm{~kg} \mathrm{ha}^{-1}$ dan 750 $\mathrm{kg} \mathrm{ha}^{-1}$ yang diinokulasi CMA $5 \mathrm{~g} \mathrm{koker}^{-1}$ semai dan $10 \mathrm{~g}$ koker $^{-1}$ semai menghasilkan jumlah buah per tanaman tidak berbeda nyata dan bahkan cenderung lebih banyak dibandingkan dengan perlakukan yang dipupuk NPK $1000 \mathrm{~kg} \mathrm{ha}^{-1}$ dengan tanpa diinokulasi CMA. Hal ini menunjukkan bahwa keberadaan CMA dalam sistem pertumbuhan tanaman tomat dapat meningkatkan efisiensi penggunaan pupuk 
NPK. Hal ini karena kolonisasi CMA pada akar tanaman akan menginduksi hipertrofi akar, yang mengakibatkan rangsangan tumbuhnya rambut-rambut akar menjadi lebih cepat. Akar tanaman yang memiliki persentase infeksi akar yang tinggi akan lebih banyak mensekresikan hormon rizokalin, sehingga luas dan volume permukaan akar menjadi lebih besar (Meisilva et al., 2019).

Sejalan dengan penelitian Prayudyaningsih (2014), yang menyatakan bahwa CMA yang menginfeksi akar tanaman berperan dalam perbaikan nutrisi tanaman dan meningkatkan pertumbuhan, karena hifa yang menginfeksi akar mempunyai kemampuan yang tinggi dalam meningkatkan kapasitas penyerapan unsur fosfat, nitrogen, sulfur, seng dan unsur-unsur esensial lainnya. Laju penyerapan unsur hara oleh akar tanaman dengan ada CMA bertambah empat kali lipat dibandingkan dengan yang tidak ada CMA, demikian pula luas penyerapan akar makin bertambah hingga 80 kali.

\section{Bobot buah per tanaman}

Seperti halnya pada jumlah buah per tanaman, interaksi antara inokulasi CMA dengan pemupukan NPK berpengaruh nyata terhadap bobot buah per tanaman. Hal ini karena jumlah buah yang terbentuk merupakan komponen penting yang dapat mempengaruhi besaran hasil buah per tanaman. Pengaruh interaksi antara inokulasi CMA dengan pemupukan NPK terhadap bobot buah tomat per tanaman disajikan pada Tabel 4.

Pada perlakuan yang tidak dipupuk NPK dan yang dipupuk NPK $1000 \mathrm{~kg} \mathrm{ha}^{-1}$ inokulasi CMA tidak berpengaruh nyata terhadap bobot buah per tanaman. Sedangkan pada perlakuan yang dipupuk NPK dengan dosis $250 \mathrm{~kg} \mathrm{ha}^{-1}, 500 \mathrm{~kg} \mathrm{ha}^{-1}$ dan $750 \mathrm{~kg}$ ha $^{-1}$, inokulasi CMA $5 \mathrm{~g}_{\text {koker }}{ }^{-1}$ semai dan $10 \mathrm{~g} \mathrm{koker}^{-1}$ semai menghasilkan bobot buah per tanaman lebih tinggi dan berbeda nyata dibandingkan dengan yang tidak diinokulasi CMA.

Tabel 4. Pengaruh interaksi antara inokulasi CMA dengan pemupukan NPK terhadap bobot buah tomat

\begin{tabular}{cccc}
\hline $\begin{array}{c}\text { Dosis } \\
\text { pupuk } \\
\text { NPK } \\
\left(\mathrm{kg} \mathrm{ha}^{-1}\right)\end{array}$ & \multicolumn{3}{c}{$\begin{array}{c}\text { Inokulasi CMA } \\
\left.\text { (g koker }{ }^{-1} \text { semai }\right)\end{array}$} \\
\cline { 2 - 4 } & 0 & 5 & 10 \\
\hline \multicolumn{4}{c}{-----kg----- } \\
& $0,48 \mathrm{a}$ & $0,52 \mathrm{a}$ & $0,53 \mathrm{a}$ \\
250 & $\mathrm{~A}$ & $\mathrm{~A}$ & $\mathrm{~A}$ \\
& $1,10 \mathrm{~b}$ & $1,40 \mathrm{~b}$ & $1,44 \mathrm{~b}$ \\
500 & $\mathrm{~A}$ & $\mathrm{~B}$ & $\mathrm{~B}$ \\
& $2,54 \mathrm{c}$ & $2,94 \mathrm{c}$ & $3,01 \mathrm{c}$ \\
750 & $\mathrm{~A}$ & $\mathrm{~B}$ & $\mathrm{~B}$ \\
& $2,58 \mathrm{c}$ & $2,97 \mathrm{c}$ & $3,03 \mathrm{c}$ \\
1000 & $\mathrm{~A}$ & $\mathrm{~B}$ & $\mathrm{~B}$ \\
& $2,81 \mathrm{~d}$ & $2,83 \mathrm{c}$ & $2,89 \mathrm{c}$ \\
& $\mathrm{A}$ & $\mathrm{A}$ & $\mathrm{A}$ \\
\hline
\end{tabular}

Keterangan : Angka rerata yang diikuti huruf besar yang sama arah horizontal dan huruf kecil yang sama arah vertikal tidak berbeda menurut uji jarak berganda Duncan pada taraf nyata $5 \%$.

Pemupukan NPK pada tanaman tomat dengan dosis $500 \mathrm{~kg} \mathrm{ha}^{-1}$ dan $750 \mathrm{~kg}$ ha $^{-1}$ dan diinokulasi CMA 5 g koker $^{-1}$ semai dan $10 \mathrm{~g} \mathrm{koker}^{-1}$ semai menghasilkan bobot buah per tanaman lebih tinggi dibandingkan dengan yang dipupuk NPK $1000 \mathrm{~kg} \mathrm{ha}^{-1}$ dengan tanpa dinokulasi CMA. Sebagaimana telah dijelaskan di atas, CMA akan menginfeksi akar tanaman dapat berperan dalam perbaikan nutrisi tanaman dan meningkatkan pertumbuhan tanaman, karena hifa yang menginfeksi akar mempunyai kemampuan dalam meningkatkan kapasitas penyerapan unsur fosfat, nitrogen, sulfur, seng dan unsur-unsur esensial lainnya yang dibutuhkan tanaman.

Serapan $\mathrm{N}$ yang tinggi oleh tanaman menyebabkan pembentukan protein yang lebih tinggi, unsur $\mathrm{P}$ akan mengoptimalkan proses fisiologis tanaman seperti fotosintesis dan respirasi, sedangkan $\mathrm{K}$ mengoptimalkan transportasi unsur hara dan asimilat dari 
daun keseluruh jaringan (Satria et al., 2015), sehingga mengakibatkan fotosintat bertambah dan meningkatkan hasil buah.

\section{Bobot buah per hektar}

Bobot buah per hektar merupakan komponen penting untuk mengetahui tingkat produktivitas yang dicapai oleh tanaman tomat per satuan luas akibat suatu perlakuan. Analisis ragam menunjukkan bahwa terdapat interaksi antara inokulasi CMA dengan pemupukan NPK terhadap bobot buah tomat per hektar. Untuk lebih rinci dapat dilihat pada Tabel 5 .

Tabel 5. Pengaruh interaksi antara inokulasi CMA dengan pemupukan NPK terhadap bobot buah tomat per hektar $\left(\mathrm{t} \mathrm{ha}^{-1}\right)$.

\begin{tabular}{cccc}
\hline $\begin{array}{c}\text { Dosis } \\
\text { pupuk } \\
\text { NPK } \\
\left(\mathrm{kg} \mathrm{ha}^{-1}\right)\end{array}$ & \multicolumn{4}{c}{$\begin{array}{c}\text { Inokulasi CMA } \\
\text { (g koker }{ }^{-1} \text { semai) }\end{array}$} \\
\cline { 2 - 4 } & 0 & 5 & 10 \\
\hline & \multicolumn{4}{c}{-----ton ha -1----- $^{-1}$} \\
& $12,80 \mathrm{a}$ & $13,86 \mathrm{a}$ & $14,13 \mathrm{a}$ \\
& $\mathrm{A}$ & $\mathrm{A}$ & $\mathrm{A}$ \\
250 & $29,33 \mathrm{~b}$ & $37,33 \mathrm{~b}$ & $38,40 \mathrm{~b}$ \\
& $\mathrm{~A}$ & $\mathrm{~B}$ & $\mathrm{~B}$ \\
500 & $67,73 \mathrm{c}$ & $78,39 \mathrm{c}$ & $80,25 \mathrm{c}$ \\
& $\mathrm{A}$ & $\mathrm{B}$ & $\mathrm{B}$ \\
750 & $68,93 \mathrm{c}$ & $79,19 \mathrm{c}$ & $80,80 \mathrm{c}$ \\
& $\mathrm{A}$ & $\mathrm{B}$ & $\mathrm{B}$ \\
1000 & $74,93 \mathrm{~d}$ & $75,46 \mathrm{c}$ & $77,06 \mathrm{c}$ \\
& $\mathrm{A}$ & $\mathrm{A}$ & $\mathrm{A}$ \\
\hline
\end{tabular}

Keterangan : Angka rerata yang diikuti huruf besar yang sama arah horizontal dan huruf kecil yang sama arah vertikal tidak berbeda menurut uji jarak berganda Duncan pada taraf nyata 5\%.

Pada Tabel 5 menunjukkan bahwa pada pemupukan NPK dengan dosis $250 \mathrm{~kg}$ $\mathrm{ha}^{-1}, 500 \mathrm{~kg} \mathrm{ha}^{-1}$ dan $750 \mathrm{~kg} \mathrm{ha}^{-1}$ yang diinokulasi CMA 5 g koker $^{-1}$ semai dan 10 g koker-1 semai menghasilkan bobot buah per hektar lebih tinggi dan berbeda nyata dibandingkan dengan yang tidak diinokulasi CMA. Inokulasi CMA $5 \mathrm{~g} \mathrm{koker}^{-1}$ semai dengan $10 \mathrm{~g} \mathrm{koker}^{-1}$ semai pada masing- masing dosis pupuk NPK tersebut di atas berbeda tidak nyata. Pada perlakuan yang dipupuk NPK $1000 \mathrm{~kg} \mathrm{ha}^{-1}$ inokulasi CMA tidak pengaruh nyata terhadap bobot buah per hektar. Hal ini kemungkinan pada pemupukan NPK dengan dosis $1000 \mathrm{~kg} \mathrm{ha}^{-1}$ tidak terjadi interaksi atau simbiosis antara akar tanaman tomat dengan CMA, karena kebutuhan unsur oleh tanaman sudah dapat tercukupi dengan pemberian pupuk NPK sebanyak $1000 \mathrm{~kg} \mathrm{ha}^{-1}$.

Pemupukan NPK menunjukkan pengaruh berbeda-berda terhadap bobot buah per hektar tergantung dosis inokulan CMA yang diberikan. Pada perlakuan tanpa inokulasi CMA hasil buah per hektar tertinggi didapat pada pemupukan NPK dosis $1000 \mathrm{~kg} \mathrm{ha}^{-1}$, yang berbeda nyata dengan perlakuan yang dipupuk NPK dosis $250 \mathrm{~kg} \mathrm{ha}^{-1}, 500 \mathrm{~kg} \mathrm{ha}^{-1}$ dan $750 \mathrm{~kg} \mathrm{ha}^{-1}$. Dosis pupuk NPK $1000 \mathrm{~kg} \mathrm{ha}^{-1}$ merupakan dosis yang umum digunakan oleh petani tomat atau sebagai dosis rekomendasi untuk tanaman tomat.

Pada perlakuan inokulasi CMA $5 \mathrm{~g}$ koker $^{-1}$ semai dan $10 \mathrm{~g}$ koker $^{-1}$ semai pemupukan NPK dengan dosis $500 \mathrm{~kg} \mathrm{ha}^{-1}$, $750 \mathrm{~kg} \mathrm{ha}^{-1}$ dan $1000 \mathrm{~kg} \mathrm{ha}^{-1}$ satu sama lainnya berbeda tidak nyata. Pada penelitian ini terlihat pemupukan NPK dosis $500 \mathrm{~kg}$ $\mathrm{ha}^{-1}$ dan $750 \mathrm{~kg} \mathrm{ha}^{-1}$ dengan inokulasi CMA dosis 5 g koker ${ }^{-1}$ semai dan 10 g koker $^{-1}$ semai walaupun tidak nyata cenderung menghasilkan bobot buah per hektar lebih tinggi dibandingkan dengan yang dipupuk NPK $1000 \mathrm{~kg} \mathrm{ha}^{-1}$. Hal ini menunjukkan bahwa pemberian pupuk NPK dengan dosis maksimum jika diinokulasi CMA dapat menyebabkan tanaman kelebihan unsur hara sehingga menjadi faktor pembatas terhadap hasil tanaman.

Aplikasi pupuk NPK yang berlebihan dapat menurunkan $\mathrm{pH}$ tanah dan serapan unsur hara karena menjadi bentuk yang tidak tersedia di dalam tanah. Menurut Satria et al., (2015), penambahan unsur hara 
yang berlebihan melalui pemupukan dapat bersifat racun dan mengakibatkan ketersediaan unsur mikro seperti $\mathrm{Zn}, \mathrm{Fe}$ dan $\mathrm{Cu}$ berkurang serta mempersulit penyerapan unsur Mn sehingga pertumbuhan tanaman terhambat. Penambahan pupuk akan meningkatkan produksi tanaman, tetapi pada suatu titik tertentu penambahan pupuk berikutnya akan menurunkan hasil tanaman (Handayanto, et al., 2017).

Pada Tabel 5 juga terlihat bahwa pemupukan NPK dengan dosis $500 \mathrm{~kg} \mathrm{ha}^{-1}$ dan $750 \mathrm{~kg} \mathrm{ha}^{-1}$ dengan inokulasi CMA $5 \mathrm{~g}$ koker $^{-1}$ semai dan $10 \mathrm{~g}$ koker $^{-1}$ semai menghasilkan bobot buah per hektar lebih tinggi dibandingkan dengan perlakuan yang dipupuk NPK $1000 \quad \mathrm{~kg}^{\text {ha }}{ }^{-1}$ tanpa diinokulasi CMA. Bobot buah per hektar tertinggi didapat pada perlakuan dosis pupuk NPK $500 \mathrm{~kg} \mathrm{ha}^{-1}$ dan $750 \mathrm{~kg} \mathrm{ha}^{-1}$ dengan inokulasi CMA 10 g koker $^{-1}$ semai yaitu masing-masing sebanyak $80,25 \mathrm{t} \mathrm{ha}^{-1}$ dan $80,80 \mathrm{t} \mathrm{ha}^{-1}$ atau meningkat masingmasing sebesar $7,09 \%$ dan $7,82 \%$ dari pemupukan $1000 \mathrm{~kg} \mathrm{ha}^{-1}$ tanpa inokulasi. Inokulasi CMA $10 \mathrm{~g} \mathrm{koker}^{-1}$ semai mampu mengefisiensikan penggunaan NPK sebesar $250 \mathrm{~kg} \mathrm{ha}^{-1}(25 \%)$ sampai $500 \mathrm{~kg} \mathrm{ha}{ }^{-1}$ $(50 \%)$ dari dosis rekomendasi atau dosis NPK yang biasa digunakan oleh petani tomat.

Keberadaan cendawan mikoriza arbuskular dalam sistem pertumbuhan tanaman dapat meningkatkan zona penyerapan pada daerah rizosfer (Simarmata, 2005). Seperti telah dijelaskan di atas, bahwa CMA yang menginfeksi akar tanaman berperan dalam perbaikan nutrisi tanaman dan meningkatkan pertumbuhan tanaman, karena hifa yang menginfeksi akar mempunyai kemampuan yang tinggi dalam meningkatkan kapasitas penyerapan unsur fosfat, nitrogen, sulfur, seng dan unsurunsur esensial lainnya yang dibutuhkan tanaman. Satria, et al. (2015) menyatakan bahwa serapan $\mathrm{N}$ yang tinggi oleh tanaman menyebabkan pembentukan protein yang lebih tinggi, unsur $\mathrm{P}$ akan mengoptimalkan proses fisiologis tanaman seperti fotosintesis dan respirasi, sedangkan $\mathrm{K}$ mengoptimalkan transportasi unsur hara dan asimilat dari daun ke seluruh jaringan, sehingga mengakibatkan fotosintat bertambah dan meningkatkan hasil buah.

\section{SIMPULAN}

1. Terdapat interaksi antara cendawan mikoriza arbuskular (CMA) dengan pupuk NPK terhadap luas daun, jumlah buah per tanaman, bobot buah per tanaman, dan bobot buah per hektar, tetapi pada tinggi tanaman tidak terdapat interaksi.

2. Inokulasi cendawan mikoriza arbuskular (CMA) $10 \mathrm{~g} \mathrm{koker}^{-1}$ semai dengan dipupuk NPK $500 \mathrm{~kg} \mathrm{ha}^{-1}$ dan $750 \mathrm{~kg}$ ha $^{-1}$ meningkatkan bobot buah per hektar sebesar 7,09\% dan 7,82\% dan mengurangi penggunaan pupuk NPK sebanyak $250 \mathrm{~kg} \mathrm{ha}^{-1}(25 \%)$ sampai $500 \mathrm{~kg} \mathrm{ha}^{-1}(50 \%)$ dari dosis yang biasa digunakan oleh petani atau dosis rekomendasi yaitu $1000 \mathrm{~kg} \mathrm{ha}^{-1}$.

\section{DAFTAR PUSTAKA}

Adetya, V., Nurhatika, S., \& Muhibuddin A. (2018). Pengaruh pupuk mikoriza terhadap pertumbuhan cabai rawit (Capsicum frustescens) di Tanah Pasir. Jurnal Sains dan Seni ITS, 7(2): 2337-3520.

Afrinda, M.S., \& Islami, T. (2018). Pengaruh mikoriza arbuskular dan pupuk $\mathrm{P}$ terhadap pertumbuhan dan hasil kacang tanah (Arachis hypogaea L.). Jurnal Produksi Tanaman, 6(7): 1465-1472.

Agustin, W., Ilyas, S., Budi, S.W., Anas, I, \& Suwarno, F.C. (2010). Inokulasi fungi mikoriza arbuskular (FMA) 
dan pemupukan $\mathrm{P}$ untuk meningkatkan hasil dan mutu benih cabai (Capsicum annum L.). Jurnal Agronomi Indonesia, 38(3): 218224.

Hadianur, Syafruddin, \& Kesumawati E. (2017). Pengaruh fungi mikoriza arbuskular terhadap pertumbuhan dan hasil tanaman cabai merah besar (Capsicum annum L.). Jurnal Agrotek Lestari, 3(1): 30-38.

Handayanto, E., Muddarisna, N., \& Fiqri, A. (2017). Pengelolaan Kesuburan Tanah. Malang: UB Press.

Herman M., Sasmita, K.D. \& Pranowo D. (2012). Pemanfaatan mikroba rizosfer untuk meningkatkan pertumbuhan dan serapan hara pada tanaman lada. Buletin RISTRI, 3(2): 143-150.

Kementerian Pertanian. (2018). Outlook Komoditi Tomat. Data Sistem Informasi Pertanian.

Kementerian Pertanian. (2019). Data Lima Tahun Terakhir Sub Sektor Tanaman Pangan, 2014 - 2018. http://www.pertanian.go.id/. Diakses 13 Oktober 2019.

Meisilva Erona S, Hariyadi \& Sri Wilarso Budi R. (2019). Studi pengaruh inokulasi fungi mikoriza arbuskular dan Trichordema harzianum terhadap pertumbuhan bibit vanili (Vanilla planifolia A). Prosiding Seminar dan Lokakarya V "Inovasi agroteknologi dalam mendukung percepatan swasembada pangan pokok dan lumbung pangan dunia 2045”. Persatuan Agroteknologi Indonesia. LPPM Universitas Andalas. Padang 16-17 September 2019.

Nainggolan, B. R. A. (2011). Pemberian pupuk NPK organik dan kiesrite terhadap pertambahan bibit kelapa sawit (Elaesis oleifera) di main nursery (pembibitan utama).
Skripsi. Universitas Islam Riau Pekanbaru.

Prayudaningsih, R. (2014). Pertumbuhan semai Alstonia scholaris, Acacia auriculiformis dan Muntingia calabura yang diinokulasi Fungi Mikoriza Arbuskular pada media tanah bekas tambang kapur. Jurnal Penelitian Kehutanan Walaceae, 3(1): 13-23.

Pratiwi, D.E. (2016). Uji kombinasi pupuk NPK dan pupuk hayati terhadap pertumbuhan dan hasil tanaman melon (Cucumis melo L.). Skripsi. Fakultas Pertanian Universitas Jenderal Soedirman. Purwokerto.

Sastrahidayat, I.R. (2010). Rekayasa Pupuk Hayati Mikoriza dalam Meningkatkan Produksi Pertanian. Malang: UB Press.

Satria, N., Wardati, \& Khoiri, M.A. (2015). Pengaruh pemberian kompos tandan kosong kelapa sawit dan pupuk NPK terhadap pertumbuhan bibit tanaman gaharu (Aquilaria malaccencis). JOM Faperta. 2(1).

Simarmata, T. (2005). Aplikasi pupuk biologis dan pupuk organik untuk meningkatkan kesehatan tanah dan hasil tanaman tomat (Lycopersicon esculentum Mill.). Jurnal Agroland, 12(3): 261-266.

Subhan, Nurtika N., \& Gunadi N. (2009). Respons tanaman tomat terhadap penggunaan pupuk majemuk NPK 15-15-15 pada tanah latosol pada musim kemarau. Jurnal Hortikultura, 19(1): 40-48.

Suwahyono, U. (2011). Petunjuk Praktis Penggunaan Pupuk Organik secara Efektif dan Efisien. Jakarta: Penebar Swadaya.

Trisilawati, O., Towaha J., \& Daras U. (2012). Pengaruh mikoriza dan pupuk NPK terhadap pertumbuhan 
dan produksi jambu mete muda. Buletin RISTRI. 3(1): 91-98.

Wasonowati, C. (2011). Meningkatkan pertumbuhan tanaman tomat (Lycopersicum esculentum) dengan system budidaya hidroponik. Agrovigor. 4(1): 21-28. 